\title{
Analisis Pendapatan dan Kelayakan Usahatani Cabai Rawit di Desa Kesambi Kecamatan Mejobo Kabupaten Kudus
}

\section{(Analysis of Income and Expenditure of Cayenne Farming System in Kesambi Village Mejobo District Kudus Regency)}

\author{
M. Faela Sofa", Saparto") dan Sumardi") \\ "Alumnus STIP Farming Semarang \\ ") Dosen STIP Farming Semarang \\ Email :sm.faela@yahoo.com, saparto.saparto@gmail.com, yos.sumardi@gmail.com
}

\section{ABSTRAK}

Penelitian bertujuan untuk mengetahui pendapatan usahatani dan kelayakan finansial usahatani cabai rawit. Penelitian dilakukan di Ds Kesambi Kec Mejobo Kab Kudus bulan September 2018 s.d Juli 2019. Jumlah petani \pm 130 orang dengan luas lahan berkisar 0,100 s.d. 0,500 ha. Survei dilakukan dengan metode sampling Stratified Random Sampling, jumlah sampel $25 \%$ atau 33 responden. Pengumpulan data dengan wawancara dan pengamatan. Data meliputi data biaya pengeluaran berupa biaya : bibit, pupuk, pestisida, tenaga kerja, penyusutan peralatan, sewa lahan, sewa mesin, dan pajak. Data penerimaan diperoleh dari data produksi dikalikan harga jual. Analisis data : Pendapatan dianalisis dengan analisis biaya dan penerimaan; kelayakan dianalisis dengan RCR, BEP, dan ROI. Hasil penelitian : (1) Rata-rata pendapatan sebesar Rp. 42.499.673,-/ha; RCR = 2,10, $\mathrm{BEP}_{(\mathrm{Q})}=2.653,14 \mathrm{~kg} / \mathrm{ha}$ ( $\left.\mathrm{riil}=5.580,7\right), \mathrm{BEP}_{(\mathrm{Rp})}=\mathrm{Rp} .6 .894,-(\mathrm{riil}=\mathrm{Rp}$. $14.500,-),, \mathrm{ROI}=110,34 \%$ (bungan Bank $=12 \% /$ th). (2) Kesimpulan : usahatani cabai rawit di Desa Kesambi Kecamatan Mejobo Kabupaten Kudus menguntungkan dan layak secara finansial.

\section{Kata kunci : pendapatan, kelayakan, cabai rawit}

\section{ABSTRACT}

The study aims to determine farm income and financial viability of chili farming. The study was conducted in Kesambi Village, Mejobo Subdistrict, Kudus Regency, in September 2018, July 2019. The number of farmers \pm 130 farmers with an area of around 0,100. 0.500 ha. The survey was conducted using the Stratified Random Sampling method, the number of samples was $25 \%$ or 33 respondents. Data collection by interview and observation. Data includes expenditure data in the form of costs: seeds, fertilizers, pesticides, labor, equipment depreciation, land rent, machine rental, and taxes. Receipt data is obtained from production data multiplied by selling prices. Data analysis: Revenues were analyzed by cost analysis and revenue; feasibility analyzed with RCR, $B E P$, and ROI. Research results: (1) Average income of Rp. 42,499,673, $-/$ ha; $R C R=2.10, B E P(Q)$ $=2,653.14 \mathrm{~kg} / \mathrm{ha}(\mathrm{real}=5,580.7), B E P(R p)=R p .6,894,-(\mathrm{real}=R p .14,500,-), R O \mathrm{I}=110.34 \%$ (Bank interest $=12 \%)$. (2) Conclusion: cayenne farming in Kesambi Village, Mejobo Subdistrict, Kudus Regency is profitable and financially feasible.

Keywords: income, feasibility, cayenne pepper

\section{PENDAHULUAN}

Kabupaten Kudus berpotensi untuk dikembangkan usaha tanaman cabai rawit yang banyak dikonsumsi masyarakat sebagai bumbu masakan dan dipercaya dapat meningkatkan selera makan bagi sebagian orang (Setiadi, 2005). Cabai rawit juga banyak dibutuhkan pada industri makanan kaleng, saus dan industri obat-obatan.

Prajnanta (1999) menyatakan bahwa cabai mengandung protein, lemak, karbohidrat, kalsium (Ca), fosfor $(P)$, besi $(\mathrm{Fe})$, vitamin-vitamin, dan mengandung senyawa-senyawa alkaloid, seperti capsaicin, flavenoid, dan minyak esensial. 
Suratiyah (2015) menyatakan usahatani adalah ilmu yang mempelajari bagaimana seseorang mengusahakan dan mengkoordinir faktor-faktor produksi berupa lahan dan alam sekitarnya sebagai modal hingga memberikan manfaat yang sebaik-baiknya. Soekartawi (2006) menyatakan tujuan berusahatani adalah memaksimalkan keuntungan atau meminimumkan biaya. Konsep memaksimalkan keuntungan adalah bagaimana mengalokasikan sumberdaya dengan jumlah tertentu seefisien mungkin untuk mendapatkan keuntungan maksimum. Sedangkan konsep meminimalkan biaya, yaitu bagaimana menekan biaya sekecil mungkin untuk mencapai tingkat produksi tertentu.

Usahatani cabai rawit yang dilakukan petani kecil umumnya masih dilakukan secara sederhana dan teknologi produksi dilakukan secara turun menurun. Penggunaan biaya sarana produksi dan biaya lainnya belum banyak dikaji secara bisnis yang teliti.

Agar usahatani dapat tumbuh dan berkembang maka petani dituntut agar usahataninya berorientasi kepada keuntungan. Untuk itu harus diupayakan peningkatan kemampuan dan ketrampilan petani dalam melaksanakan usahataninya. Penelitian ini bertujuan untuk mengetahui tingkat pendapatan dan kelayakan usahatani cabai rawit di Desa Kesambi Kecamatan Mejobo Kabupaten Kudus.

\section{MATERI DAN METODE Lokasi dan Waktu Penelitian}

Penelitian dilakukan di Desa Kesambi Kecamatan Mejobo Kabupaten Kudus bulan September 2018 s.d. Juli 2019. Desa tersebut banyak jumlah petani cabai rawitnya, dan merupakan daerah pengembangan diversifikasi untuk meningkatkan pendapatan. Petani masih beragam dalam menggunakan sarana produksinya. Perhitungan analisis finansial seperti tingkat pendapatan dan kelayakan finansial belum diperhitungkan secara agribisnis.

\section{Metode Penelitian dan Penentuan Sampel}

Penelitian dilakukan dengan survei. Ada sekitar 130 orang petani. Metode pengambilan sampel dengan metode Stratified Random Sampling karena dianggap luas kepemilikan lahan cukup beragam yaitu berkisar $0,100 \mathrm{sd}$ 0,500 ha. Strata dilakukan atas dasar luas lahan dan ditetapkan dibagi menjadi 3 (tiga) strata. Jumlah sampel responden ditetapkan sebanyak $25 \%$ dari populasi, sehingga diperoleh jumlah sampel responden sebanyak 33 petani sebagai responden (Arikunto, 1998).

\section{Metode Pengumpulan Data}

Data primer dilakukan dengan wawancara dipandu dengan daftar pertanyaan, serta dilakukan pengamatan (observation) terhadap data yang diperoleh di lapangan. Data berkaitan dengan biaya yang dikeluarkan untuk produksi cabai dan penerimaan. Biaya tetap berupa penyusutan peralatan, sewa tanah, sewa mesin, pajak. Biaya variabel berupa biaya pembelian sarana produksi (bibit, pupuk, pestisida), dan tenaga kerja.

\section{Analisis Data}

Pendapatan dianalisis dengan menggunakan analisis biaya dan penerimaan. Penerimaan merupakan penerimaan dari penjualan hasil produksi. Pendapatan bersih merupakan selisih antara total biaya dan pendapatan kotor/penerimaan (Soekartawi, 2002). Kelayakan usahatani dianalisis dengan rumus : Revenue Cost Ratio (RCR), Break Event Point (BEP), dan Return on Investment (ROI) 
HASIL DAN PEMBAHASAN

Rekapitulasi hasil perhitungan pendapatan dan kelayakan finansial disajikan pada Tabel 1.

Tabel 1. Biaya Produksi, Penerimaan,Pendapatan dan Kelayakan Usahatani Cabai Rawit per Hektar di Desa Kesambi Kecamatan Mejobo Kabupaten Kudus.

\begin{tabular}{|c|c|c|c|c|}
\hline No & Uraian & Nilai (Rp) & Riil & Kesimpulan \\
\hline 1. & Biaya Tetap & & & \\
\hline & a. Sewa Lahan & 8.264 .708 & & \\
\hline & b. Pajak & 165.295 & & \\
\hline & c. Sewa Mesin & 7.323 .602 & & \\
\hline & Total Biaya Tetap & 15.753 .605 & & \\
\hline 2. & Biaya Variabel & & & \\
\hline & a. Bibit & 1.090 .950 & & \\
\hline & b. Pupuk & 8.126 .856 & & \\
\hline & c. Pestisida & 3.850 .733 & & \\
\hline & d. Tenaga Kerja & 9.648 .391 & & \\
\hline & Total Biaya Variabel & 22.716 .930 & & \\
\hline 3. & Total Biaya Produksi & 38.470 .353 & & \\
\hline 4. & Total Produksi (kg) & 5.581 & & \\
\hline 5. & Harga Satuan & 14.500 & & \\
\hline 6. & Total Penerimaan & 80.920 .208 & & \\
\hline 7. & Pendapatan Bersih & 42.449 .673 & & \\
\hline 8. & RCR & 2,04 & $>1$ & Layak \\
\hline 9. & $\mathrm{BEP}_{(\mathrm{Q})}(\mathrm{kg})$ & $2.575,11$ & $5.580,70$ & Layak \\
\hline 10. & $\mathrm{BEP}_{(\mathrm{Rp})}(\mathrm{Rp})$ & 6.692 & 14.500 & Layak \\
\hline 11. & ROI (\%) & 110,34 & $>12 \%$ (setahun) & Layak \\
\hline
\end{tabular}

Sumber: Data Primer diolah.

\section{A. Analisis Pendapatan Usahatani Cabai Rawit}

Tabel 1. usahatani cabai rawit diperoleh produksi sebanyak $5.581 \mathrm{~kg}$ dengan harga jual Rp.14.500,-/kg sehingga diperoleh penerimaan sebesar Rp 80.920.208. Total biaya produksi sebesar Rp. 38.470.353,-. Dengan demikian diperoleh pendapatan sebesar Rp 42.499.673,- per hektar.

Pendapatan ini relatif lebih besar dibanding hasil penelitaian Agnes dan Antara ( 2017) sebesar Rp. 11.101.482,-, namun lebih rendah dibanding Kurniawan et al. (2013) sebesar Rp.57.267.985,-/ha; Husni et al. (2014) sebesar Rp. 84.021.430,-/ha dan Daryatmi et al. (2017) sebesar Rp. 575.459.438,-/hektar. Agnes dan Antara (2017) memperoleh produksi $1.145,11 \mathrm{~kg}$ dan dengan harga Rp 15.000,-/kg, sehingga pendapatannya lebih rendah dibanding hasil penelitian ini.
Sedangkan Daryatmi et al. (2017) memperoleh produksi $5.319,52 \mathrm{~kg}$ dengan harga Rp.23.481,- sehingga pendapatannya lebih besar dibanding hasil penelitian ini. Produksi yang rendah dari hasil penelitian Agnes dan Antara ini dimungkinkan salah satu penyebabnya adalah penggunaan biaya pupuk yang rendah yaitu $16,64 \%$ dibanding hasil penelitian ini sebesar 21,12\%. Maruli, Ernita dan H. Gultom (2012) dalam penelitiannya menyatakan bahwa pemberian NPK Grower dan Kompos memberikan pengaruh yang nyata terhadap umur berbunga, umur panen dan berat buah pertanaman. Penurunan produksi juga bisa disebabkan karena kerontokan bungan dan buah. Selanjutnya Lingga dan Marsono (2001) menyatakan bahwa cara mengatasi kerontokan bunga dapat menggunakan pupuk Kalium. Pupuk Kalium dapat 
memperkuat tubuh tanaman agar bunga, buah dan daun tidak mudah rontok. Selain itu pupuk Kalium juga dapat membantu pembentukan protein dan Karbohidrat serta menghasilkan ketahanan tanaman terhadap cekaman kekeringan.

Palar et al. (2016) menyatakan bahwa permintaan cabai rawit berpengaruh terhadap harga cabai, ketika permintaan meningkat maka harga juga meningkat begitupun sebaliknya. Harga barang substitusi, harga barang pelengkap, dan selera juga mempengaruhi harga cabai rawit. Sehingga perbedaan pendapatan ini secara garis besar dipengaruhi oleh perbedaan : (1) tingkat produksi cabai rawit; dan (2) tingkat harga jual cabai rawit.

\section{B. Kelayakan Usahatani Cabai Rawit 1. RCR \\ RCR usahatani cabai rawit di}

Desa Kesambi sebesar 2,04 > 1, maka setiap pengeluaran Rp. 1.000,- akan memberikan penerimaan Rp. 2.020,sehingga layak secara finansial untuk diusahakan. Nilai RCR ini lebih besar dibanding hasil penelitian Kurnia et al. (2013) sebesar 1,69. Namun RCR tersebut lebih kecil dibanding nilai RCR hasil penelitian Daryatmi et al. (2017) dan Agnes dan Antara (2017) dengan nilai RCR sebesar 15,27 dan 2,69.

2. BEP

a. BEP Produksi/ BEP ( $Q$ )

Tabel 1. menunjukkan rata-rata BEP produksi $2.575,11 \mathrm{~kg} / \mathrm{ha}$ sedangkan produksi riil sebesar $5.580,70 \mathrm{~kg} / \mathrm{ha}$, berarti terdapat keuntungan 3.005,59 $\mathrm{kg} / \mathrm{ha}$, sehingga layak diusahakan. Penelitian Husni, et al (2014), BEP produksi yaitu $5.786 \mathrm{~kg} / \mathrm{ha}$ sedangkan produksi riil $13.522 \mathrm{~kg} / \mathrm{ha}$.

a. BEP Harga/ BEP (Rp)

Berdasarkan Tabel 1. rata-rata
BEP harga sebesar Rp. 6.692,-/kg sedangkan harga riil dipasar mencapai Rp.14.500,-/kg, maka terdapat selisih keuntungan harga sebesar Rp. 7.808,-/kg, selisih harga ini dapat dipengaruhi oleh naiknya harga saat penelitian. BEP (Rp) < harga pasar yang berarti layak diusahakan. Husni et al. (2014) melaporkan bahwa $\operatorname{BEP}_{(\mathrm{Rp})}=$ Rp.6.520,$/ \mathrm{kg}$, sedangkan harga riil Rp. 12.000,0/kg.

\section{b. ROI}

Hasil analisis kelayakan diperoleh ROI sebesar $110,34 \%$, yang berarti memperoleh keuntungan sebesar 10,34\% selama tanam dan ini lebih besar dari tingkat suku bunga bank yang berlaku $(12 \%)$ setahun, sehingga layak untuk diusahakan. ROI $110,34 \%$ ini menggambarkan bahwa dari modal $100,00 \%$ yang dikeluarkan akan menghasilkan pendapatan sebesar $10,34 \%$ selama musim tanam.

\section{KESIMPULAN DAN SARAN}

\section{a. Kesimpulan}

Usahatani cabai rawit di Desa Kesambi Kecamatan Mejobo Kabupaten Kudus menguntungkan sebesar $\mathrm{Rp}$. 42.449.673,-/ha, dan layak secara finansial untuk diusahakan.

\section{b. Saran}

Perlu ditingkatkan efisiensi penggunaan biaya sarana produksi dan tenaga kerja, dan untuk ini perlu diteliti tentang hal tersebut.

\section{DAFTAR PUSTAKA}

Agnes, A., dan M. Antara. 2017. Analisis Pendapatan dan Kelayakan Usahatani Cabai Rawit di Desa Sunju Kecamatan Marawola Kabupaten Sigi. E-J. Agrotekbis 5(1) : 86-91, Februari 2017. 
Arikunto, S. 1998. Metodologi Penelitian Sosial Ekonomi. Penebar Swadaya, Jakarta.

Daryatmi., A. Astuti, I.S. Sudrajat. 2017. Analisis Biaya, Pendapatan dan Efisiensi Usahatani Cabai Rawit (Capsicum frutescens, L). (Studi Kasus di Kecamatan Kedu Kabupaten Temanggung). J. Agritas. Vol.1., No.1. 2017.

Husni., A.K. Hidayah, dan Maskan AF. 2014. Analisis Finansial Usahatani Cabai Rawit (Capsicum frutescens, L.) di Desa Purwajaya Kecamatanh Loa Janan. Jurnal AGRIFOR Volume XIII Nomor 1, Maret 2014; 49-52

Kurniawan, R.P., E. Istiyanti, dan U. Hasanah. 2013. Analisis Usahatani Cabai Rawit (Capsicum frutescens, L.) di Lahan Tegalan Desa Ketawangrejo Kecamatan Grabag Kabupaten Purworejo. SURYA AGRITAMA Volume 2, Nomor 1, Maret 2013; 76-87

Lingga, P., dan Marsono. 2001. Petunjuk Penggunaan Pupuk. Jakarta: Penebar Swadaya.
Maruli, Ernita dan H. Gultom. 2012. Pengaruh Pemberian NPK Grower dan Kompos terhadap Pertumbuhan dan Produksi Tanaman Cabe Rawit (Capsicum fritescent, L). Dinamika Pertanian, Vol.XXVII No.3, Desember 2012 (149-256).

Palar, N., P.A. Pangemanan, dan E.G. Tangkere. 2016. Faktor-Faktor yang Mempengaruhi Harga Cabai Rawit di Kota Manado. Agrisosioekonomi, Vol.12, No.2, Mei 2016: 105-120.

Prajnanta, F. 1999. Agribisnis Cabai Hibrida. Penebar Swadaya. Jakarta.

Setiadi, 2005. Bertanam Cabai. Penebar Swadaya. Jakarta.

Soekartawi. 2002. Prinsip Dasar Ekonomi Pertanianj. Raja Grafindo, Jakarta.

Soekartawi, 2006. Analisis Usahatani. Jakarta. UI Press.

Suratiyah, K. 2015. IImu Usahatani. Edisi Revisi. Penebar Swadaya. Jakarta Timur. 